\title{
Institutional (Dis)integration and Regional Development Implications of Whisky Tourism in Speyside, Scotland
}

\section{Arie Stoffelen \& Dominique Vanneste \\ Department of Earth \& Environmental Sciences, KU Leuven - University of Leuven, Belgium}

\begin{abstract}
Actively positioning tourism in regional socio-economic contexts and development plans is regularly seen by researchers as a prerequisite to practically unfold tourism-related regional development potential. However, conceptual elaboration and additional empirical evidence is still needed to gain a more critical understanding of this notion. Therefore, the objective of this research is to explore tourism-related delivery mechanisms for regional development by focussing on the role of tourism in larger regionbuilding processes. Using an in-depth interview based case study on the supply and policy of whisky tourism in Speyside (Scotland), we found that the mode of commodification and institutionalisation of whisky tourism in Speyside provides an unstable basis for reaching destination-wide regional development aims. Despite high-profile regional branding, the regional institutionalisation provides barriers for local stakeholders to integrate in destination management processes. Networking vehicles with multi-scalar actions are necessary to foster empowerment of local stakeholders and to facilitate regional integration of stakeholder interests. We conclude that an integrative position of tourism in the region-building process of destinations, facilitated by the mode of multi-scalar commodification and institutionalisation of territorial resources in the destination, is central for reaching tourism-induced regional development aims.
\end{abstract}

Keywords: regional development; integrated rural tourism; tourism governance; region building; whisky tourism; tourism routes; rural web; cultural landscape; place identity 
Post-print version from the article by Stoffelen \& Vanneste published in Scandinavian Journal of Hospitality and Tourism, 2015.

http://www.tandfonline.com/doi/full/10.1080/15022250.2015.1062416\#abstract

\section{Introduction}

While tourism is regularly employed as a policy strategy to reach economic and socio-cultural goals in rural and peripheral areas (Kauppila, Saarinen, \& Leinonen, 2009; Kneafsey, 2001; Saarinen, 2003), it is also characterised by a large implementation gap in unfolding these potentials (Vanneste \& Ryckaert, 2012). A general consensus among researchers has emerged that tourism development and regional development are not automatically synonymous and that critical approaches are necessary to understand and practically establish regional development based on tourism (Bramwell, 2011; Burns, 1999; Kauppila et al., 2009). Yet despite academic unity in starting points, analysis approaches are manifold. These include, for example, a focus on increasing levels of participation and empowerment, expanding the compatibility of tourism with other socio-economic, environmental and cultural aspects of destinations and improving the level of rootedness of territorial (tangible-intangible, physicalcultural) resources (Oliver \& Jenkins, 2003; Saarinen, 2003, 2007; Saxena, Clark, Oliver, \& Ilbery, 2007; Sofield, 2003).

From a destination-wide perspective, regional institutional integration of tourism in policy plans and socio-economic structures is regularly noted as one of the overarching requirements in this context (Kauppila et al., 2009; Saarinen, 2003; Timothy, 1998). Nevertheless, this relatively straightforward proposition still requires conceptual expansion and additional empirical insights to better grasp the underlying reasons for the empirical presence or absence of the implementation gap in tourism. This should allow to create knowledge on how to practically unravel the regional development potential of tourism in rural areas. Therefore, the aim of this paper is to deepen our understanding of structural delivery mechanisms for tourism-induced regional development by focussing on the role of tourism commodification and institutionalisation in larger region-building processes.

This will be empirically explored through a case study on whisky tourism in Speyside, Scotland. The high-value, multi-scalar whisky (tourism) sector with its regionalised constructivist markers related to elements of 'Scottishness' provide interesting insideroutsider structures in the Speyside destination development process. The symbolic regionbuilding role of whisky tourism, which is mostly aimed at an extra-regional audience, balances with the dependency of the sector on emplaced territorial settings that structure the spatial location of whisky production. These settings also provide tangible tourism resources 
Post-print version from the article by Stoffelen \& Vanneste published in Scandinavian Journal of Hospitality and Tourism, 2015.

http://www.tandfonline.com/doi/full/10.1080/15022250.2015.1062416\#abstract

for support of largely intangible destination images. Hence, Speyside's territorial structure renders both opportunities and bounds to reach regional development aims with tourism. Subsequently, insights into the regional institutionalisation of tourism will be combined with integrative development frameworks to create a conceptual basis for the empirical whisky tourism research. Thereafter, the case study settings will be introduced and the results of qualitative research on destination level commodification and institutionalisation of whisky tourism in Speyside will be presented. Finally, a discussion and conclusion will be presented on the impact of this institutional (dis)integration of whisky tourism on regional development delivery mechanisms.

\section{Theoretical framework}

\section{Tourism and regional development}

Regions represent the level of the multi-scalar tourism system where most destination networks are formed and where tourism resources are commodified and institutionalised (Milne \& Ateljevic, 2001). Therefore, the impact of tourism and consequent development questions have predominantly been addressed at this scale. From a destination-wide perspective, tourism is seen as a socio-cultural and economic development strategy and as an economic diversification tool to reduce dependency on traditional sectors (George, Mair, \& Reid, 2009; Hall, 2005; Kauppila et al., 2009; Saarinen, 2003, 2007). While direct economic gains of tourism largely drive regional governments and the tourism industry, tourism has more generally "been identified as a catalyst to stimulate economic growth, increase the viability of underdeveloped regions and improve the standard of living of local communities" (Briedenhann \& Wickens, 2004, p. 71). Several studies show that social, spatial and/or environmental (in)equity resulting from tourism development are key to assess the regional development impacts of tourism (Douglas, 2014; Hall, 2005; Kauppila et al., 2009; Saarinen, 2003, 2007). Building on this, tourism should lead to participation and empowerment of local stakeholders to overcome their marginalised position and to link to the tourism system (Adiyia, Stoffelen, Jennes, Vanneste, \& Ahebwa, 2015; Sofield, 2003).

Several authors state that the region and its territorial context should be central in development questions, and tourism should be actively connected in scope and management to this regional focus (Bramwell, 2010; Hall, 2005; Kauppila et al., 2009; Saarinen, 2003, 
Post-print version from the article by Stoffelen \& Vanneste published in Scandinavian Journal of Hospitality and Tourism, 2015.

http://www.tandfonline.com/doi/full/10.1080/15022250.2015.1062416\#abstract

2007; Timothy, 1998). For example, Kauppila et al. (2009) use the 'tourism first' and 'development first' tourism planning typology of Burns (1999) to review how tourism planning could facilitate regional development. In contrast to tourism first perspectives that centre on the tourism industry, development first perspectives see tourism as part of a larger regional development strategy. Tourism plans should be coherent to existing institutions and policies to keep them politically, economically and socially viable (Sofield, 2003). From this perspective, regional development is not a given consequence of tourism development. Moreover, it is not the 'absolute' quality of the destination's resources that matters most since tourism is not the sole sector on which regional development builds (Kauppila et al., 2009; Saarinen, 2003). Finally, also the mode of 'tourismification' (Jansen-Verbeke, 2013) and destination institutionalisation are key determinants for reaching regional development aims with tourism (Adiyia et al., 2015; Bramwell, 2010; Stoffelen \& Vanneste, 2015).

\section{Region-building processes}

It follows that tourism needs to be studied as part of wider region-building processes and transformations to assess the overall development potential of the sector. According to Paasi $(1996,2011)$ the regional institutionalisation that frames such region-building processes consists of four components. These are (i) its territorial shaping, in which a distinct spatial unit is created and its boundaries are delimited; (ii) its symbolic shaping, where the region is symbolically ordered and demarcated, and regional narratives are constructed; (iii) its institutional shaping, in which institutionalised social practices (re)produce territorial and symbolic shapes, and (iv) "establishment of the region as part of the regional system and social consciousness" (Paasi, 2011, p. 12). Since tourism is a key determinant of space (Hughes, 1998), for instance through the creation of tourism landscapes that physically and symbolically build on and give form to destination landscapes (Jansen-Verbeke, 2013; Ringer, 1998; Stoffelen \& Vanneste, 2015; Uusitalo, 2010), tourism can be seen as a medium in the construction and interrelation of these regional shaping processes. Because of this, tourism may be an important strategy for stakeholders to imbue their meaning and interests in the region-building process and the destination tourism landscape (Greider \& Garkovich, 1994; Knudsen, Metro-Roland, Soper, \& Greer, 2008).

Through development of distinctive destination images, tourism is thus an agent in the use of territorial resources of the destination to discursively present and portray the identity of the 
Post-print version from the article by Stoffelen \& Vanneste published in Scandinavian Journal of Hospitality and Tourism, 2015.

http://www.tandfonline.com/doi/full/10.1080/15022250.2015.1062416\#abstract

region (Paasi, 1996, 2003, 2009, 2011; Saarinen, 2004). This regional distinguishing process often implies a socially and spatially homologue situation for the destination and its inhabitants (Paasi, 2003). Yet, this neglects that the constitution of a regional identity narrative is a highly selective political-economic sphere that includes and excludes voices of specific stakeholders (Cantrill \& Senecah, 2001; Cunningham, 2009; Paasi, 2011). This process takes place across scales and locations by multiple actors, both within and outside the territorial shape of the region, providing governance complexities for inclusive management of power relations in region-building processes (Paasi, 2003, 2011; Parra, 2010). Therefore, destination development shapes "spaces of dependence through which actors can conduct their engagements" (Paasi, 2011, p. 13). Power relations, strategic interests and place-based meanings of empowered tourism stakeholders may this way become enmeshed in the institutionalisation of the region and its landscape (Bosak, Boley, \& Zaret, 2010; Greider \& Garkovich, 1994; Knudsen et al., 2008; Stoffelen \& Vanneste, 2015).

\section{Integrative regional development perspectives}

The 'integrated' perspectives to regional development form a complementary approach to study the position of tourism in regional institutionalisation processes. Generally, these relational approaches stress the importance of interconnections between actors, activities and resources within the regional system rather than optimisation of individual activities (Saxena \& Ilbery, 2008; Ventura, Brunori, Milone, \& Berti, 2008).

One example of this is the 'rural web'. According to Marsden (2010) regional development is dependent on networks, interactions and activities that determine how territorial resources are commodified, for instance for tourism purposes. Such 'webs' link human and non-human (physical-environmental) components of a territory and should allow to situate development goals in a wider regional focus (Marsden, 2010; Ventura et al., 2008). Hence, physical territorial settings of destinations can be seen as shaping the region-building process as well (Sampson \& Goodrich, 2009; Stoffelen \& Vanneste, 2015). Furthermore, governance structures and social capital are identified as enforcing mechanisms or 'lubricants' between rural web components (Hall, 2005; Marsden, 2010; Saarinen, 2007). In this context, development of tourism routes or trails can constitute strategies to turn such webs into consumption paths (Timothy \& Boyd, 2014). 
Post-print version from the article by Stoffelen \& Vanneste published in Scandinavian Journal of Hospitality and Tourism, 2015.

http://www.tandfonline.com/doi/full/10.1080/15022250.2015.1062416\#abstract

The concept of integrated rural tourism (IRT) follows a similar line of argument. IRT is tourism that is supported by social networks between local actors with an explicit connection to economic, social, cultural, natural and human resources of the destination. It builds on three elements (Oliver \& Jenkins, 2003; Saxena et al., 2007; Saxena \& Ilbery, 2008):

- Embeddedness: the integration of socio-cultural and territorial contexts in tourism development so that local knowledge and relations are included in network connections.

- Endogeneity: the retention of tourism-related benefits in a specific area by focusing on local territorial resources together with capacities and values of local people.

- Empowerment: the shift of power balances so that everyone in a tourism destination can join on an equal footing in its management and is able to benefit from this process.

A balance between embeddedness-disembeddedness and endogeneity-exogeneity is necessary to maintain dynamics in the network, increase novelty and innovation, and integrate with external markets and supra-local policy levels (Oliver \& Jenkins, 2003; Saxena et al., 2007; Saxena \& Ilbery, 2008; Ventura et al., 2008). When this balance is absent and the portrayed identity of the region contrasts with the regional consciousness of other stakeholders in the destination, the regional focus of the predominantly development oriented tourism planning perspective may be undermined. The consequent regional disintegration of tourism may reduce the capacity of disempowered stakeholders (i) to identify with the use of territorial resources in the destination (Cunningham, 2009; Waterton, 2005; Wray, Espiner, \& Perkins, 2010); (ii) to influence destination development and decision-making processes and hence management of tourism-related impacts (Ventura et al., 2008); (iii) to establish linkages between local entrepreneurs or community members and value-adding elements of the tourism system (Adiyia et al., 2015).

Therefore, an integrative position of tourism in the region-building process of the destination, facilitated by the mode of commodification and institutionalisation of destination resources, is hypothesised to be central for regional development implications of tourism (see Figure 1). The next section will analyse the development implications of the (dis)integrated regional institutionalisation of whisky tourism in Speyside, Scotland. This way, it will move beyond the dominant research focus in culinary tourism on visitor experiences and branding potentials 
Post-print version from the article by Stoffelen \& Vanneste published in Scandinavian Journal of Hospitality and Tourism, 2015.

http://www.tandfonline.com/doi/full/10.1080/15022250.2015.1062416\#abstract

of (alcoholic) beverages (see Martin \& McBoyle, 2006; McBoyle \& McBoyle, 2008;

Spracklen, 2011).

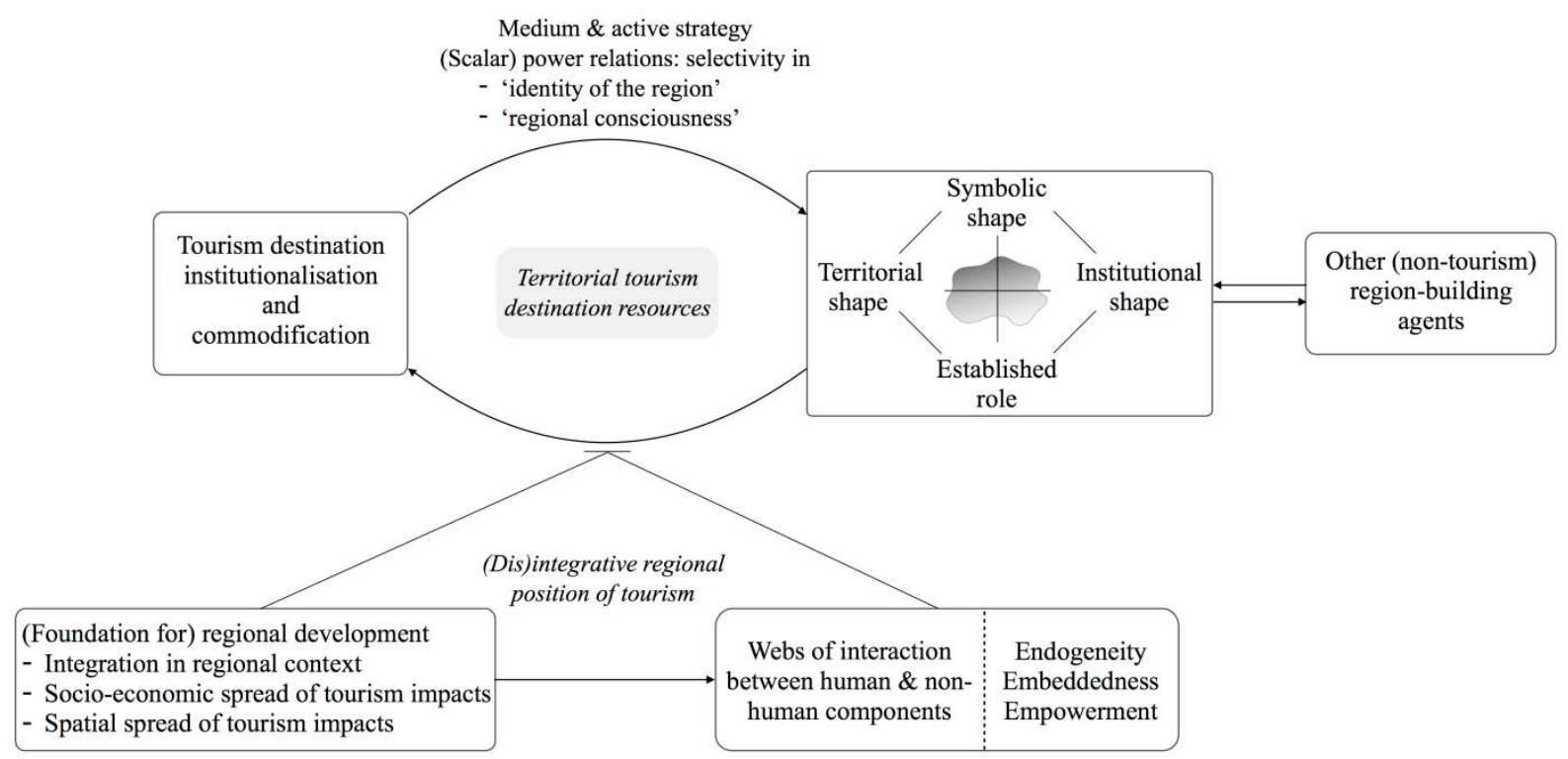

Figure 1. (Dis)integrative position and regional development structures of tourism in regionbuilding processes of destinations. Partly built on Paasi (1996, p. 34).

\section{Study area \& methodology}

Apart from being a symbol of Scottish cultural identity, whisky distillation and whisky tourism provide important benefits to the Scottish economy. The direct contribution of the whisky industry to the UK GDP is approximately 3.3 billion pounds and the sector directly supports 10,900 jobs (Scotch Whisky Association, 2015). Additionally, a 2011 study commissioned by the Scotch Whisky Association (SWA) indicated that $86 \%$ of the 1.28 million people who visited a distillery in 2010 were non-Scottish residents and the total turnover of distillery visitor centres was an estimated 26.9 million pounds (Scotch Whisky Association, 2011).

Despite these numbers, whisky production and whisky tourism benefits for Scotland have still been labelled as disappointing due to structural multi-scalar constraints of the industry (BBC Scotland, 2013; Fraser, 2013). Moreover, regional development mechanisms of whisky tourism have not yet been analysed at the destination level. 
Post-print version from the article by Stoffelen \& Vanneste published in Scandinavian Journal of Hospitality and Tourism, 2015.

http://www.tandfonline.com/doi/full/10.1080/15022250.2015.1062416\#abstract

In this light, the rural Speyside area in the northeast of Scotland has been selected to analyse the role of whisky tourism in region-building processes and the impact of this on destination level regional development. Speyside is one of five name-protected Scotch whisky regions distinguished by the SWA (2009). It is largely covered by the regional government authority of Moray Council (see Figure 2). The region is well-known because of the presence of almost half of all Scottish whisky distilleries, most of them belonging to multinational companies with global operations. Several have on-site visitor centres while some others allow visitors by appointment. Located here because of natural landscape characteristics including outstanding water quality, the distilleries significantly structure the cultural image and the tourism offerings of Speyside. Additionally, the diverse Speyside landscape, which is divided into five distinctive regions based on their physical-territorial features and regional identity (Scottish Natural Heritage, 2002), forms the basis of other important tourism activities such as hiking and fishing.

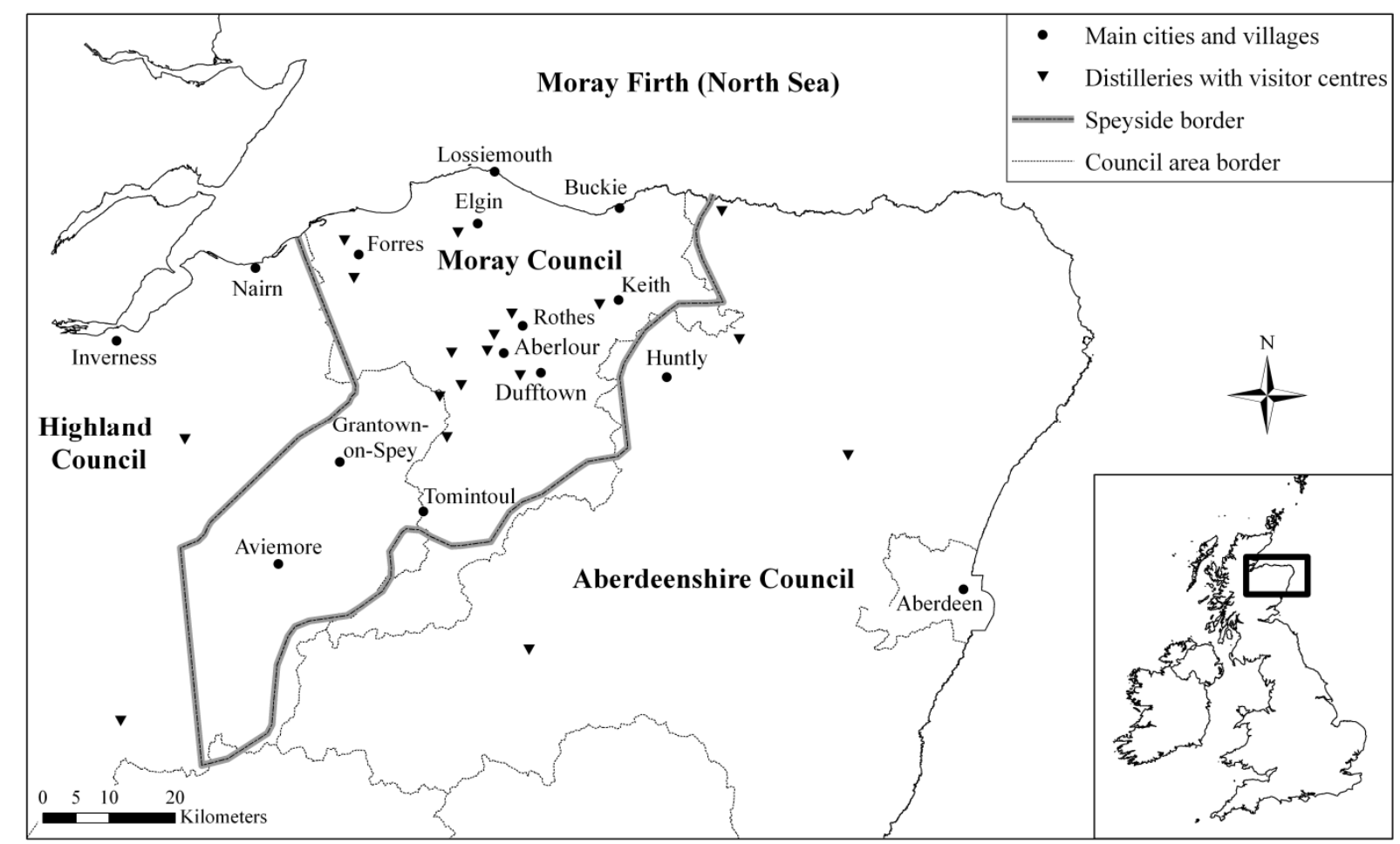

Figure 2. Overlap between Speyside and Moray Council, and the spatial spread of whisky distillery visitor centres in the area. Based on Ordnance Survey (2012) (C) Crown Copyright (unprocessed geographical data). Speyside borders are based on Scotch Whisky Association (2010). 
Post-print version from the article by Stoffelen \& Vanneste published in Scandinavian Journal of Hospitality and Tourism, 2015.

http://www.tandfonline.com/doi/full/10.1080/15022250.2015.1062416\#abstract

Qualitative fieldwork took place in Speyside between June and September 2011. It was predominantly centred on semi-structured in-depth interviews with supply and policy stakeholders who were identified and contacted with a 'snow-balling' selection process. During fieldwork the authors also visited main tourism attractions and undertook extensive countryside tours.

In total 26 interviews were conducted. Nine of these were with visitor centre managers or commercial directors of larger distillery companies. Seven interviews were conducted with coordinators of local community development organisations and the event sector as well as accommodation entrepreneurs. Six interviewees were employed by extra-local tourism governance and public sector (support) organisations. They included regional directors of Destination Management Organisations (DMOs) and development managers of regional councils and socio-economic development organisations. Finally, four community council members were also interviewed. Many of the interviewed local stakeholders were connected to both a tourism supply-side organisation and a (semi-)public body. The presence of publicprivate development and destination management organisations further enhanced this supplypolicy overlap among interviewees.

The overarching goal of the semi-structured interviews was to assess the potentials and difficulties of whisky tourism commodification for regional development of Speyside, and to analyse the role of the destination institutionalisation in this. The interviews were organised according to themes identified on the basis of tourism-related policy documents that cover Speyside and regional development-related scientific literature. The interview protocols were subsequently updated for each interview with background information on the specific organisation. Consequently, the discussed topics focused on the regional socio-economic situation and development strategies as well as local identity structures in the area; general descriptions of Speyside as a tourism destination; public-private-community cooperation structures; presence, structure and functioning of destination networks; and marketing strategies and images used to portray individual companies as well as destination as a whole. The role of the whisky industry and whisky tourism was an underlying theme throughout the discussion of these topics.

The duration of the interviews ranged from 30 minutes to two hours. All interview recordings were transcribed and, together with field notes, thematically processed in NVivo® 9. In a first coding phase, key topics were identified and thematically aggregated from the interview 
Post-print version from the article by Stoffelen \& Vanneste published in Scandinavian Journal of Hospitality and Tourism, 2015.

http://www.tandfonline.com/doi/full/10.1080/15022250.2015.1062416\#abstract

transcripts. In a second phase, the emerging topics were re-connected to the initially used policy documents and re-interpreted on the basis of a second round of literature analysis. Quotations from some of these processed interviews will be used to support the results section below.

Aiming to increase our understanding of structural delivery mechanisms for whisky tourisminduced regional development in Speyside, the results section is structured as follows. The socio-spatial institutionalisation characteristics of whisky production in Speyside will be analysed first. This is followed by an analysis of power relations in whisky tourism commodification and presentation of the regional identity. Next, global-local aspects of destination institutionalisation will be addressed. Finally, the position of whisky tourism in region-building processes and implications for regional development of the Speyside destination will be discussed.

\section{Results}

\section{Socio-spatial institutionalisation of whisky in Speyside}

The cultural landscapes of Speyside, reflecting the regional variation in physical settings as identified by Scottish Natural Heritage (2002), are characterised by relatively local and diverse socio-economic, physical and built environments. For this reason, local socioeconomic destinies are in some cases quite particular and a spatially integrating, coherent regional identity lacks amongst many of the local stakeholders. The different characteristics and contrasting mentalities of localities could be noted in the following comparison by a local community council member:

Up into Moray, into Elgin, into Forres, it's different. The land is different, the climate is different, it's a very different area to here. Very, very different. (Huntly community council member)

Local contrasts in identity and tangible (territorial) settings can even be noted for some villages that are situated close to each other in the heart of the whisky area. It also means that whisky, despite being present throughout the region, does not have a spatially even position throughout local cultural landscapes within Speyside. One example is the village of Rothes as compared to Aberlour and Dufftown (see Figure 2). The first is a rural industrial village, and 
Post-print version from the article by Stoffelen \& Vanneste published in Scandinavian Journal of Hospitality and Tourism, 2015.

http://www.tandfonline.com/doi/full/10.1080/15022250.2015.1062416\#abstract

whisky distilling has been a major source of income for many years. The same could be said for Aberlour and Dufftown, but these villages have also developed into important (mainly whisky-related) tourism attractions and many tourists by-pass Rothes to visit these places. One consequence and reinforcing structure is the presence of a community development and entrepreneurial group in Dufftown that largely focuses on tourism (Dufftown2000). A comparable organisation is not present in Rothes. Some extra-regional policy stakeholders are aware of such contrasting senses of place on local scales:

They [people of Rothes] have not really looked after tourists or visitors, so therefore they haven't really been trying to get involved in tourism. (...) Even just the feel of a place, Rothes feels more like a wee working town, whereas if you go to a place like Aberlour, there's much more of a feel of it being tourism. (Regional director, VisitScotland; the Scottish national tourism organisation)

Towards the outskirts of Speyside this relation between communities and whisky is less outspoken than close to the so-called 'malt whisky capital' of Dufftown. One example is the socio-economically struggling coastal area around the village of Buckie (see Figure 2). Despite the nearby location of some distilleries, the village has predominantly focused on fishing and offshore oil. When asked about the connection between the coastal area and the rest of Speyside, a retired community council secretary from Buckie argued:

Would I say Buckie is in Speyside? No. (...) It is very close [to the River Spey]. Buckie is very insular, I would think. It didn't look to the Spey. It didn't look inland. (Retired Buckie community council secretary)

Moreover, the council areas in Speyside (the statutory regional policy levels) are relatively new due to territorial reorganisations in the second half of the twentieth century. This has led to a complex situation where some people still identify with historic council areas, most notably Banffshire. This configuration of new administrative units and historic regions that continue to be of intangible importance for some people adds to the overall territorial and symbolic complexity:

Before we had the regions, with Aberdeenshire, with Banffshire, with Moray, you know. And they were very distinct, and very proud. But, all of a sudden when there was a local 
Post-print version from the article by Stoffelen \& Vanneste published in Scandinavian Journal of Hospitality and Tourism, 2015.

http://www.tandfonline.com/doi/full/10.1080/15022250.2015.1062416\#abstract

government reorganisation, Banffshire disappeared. Now, there was a lot of folk very upset over that, that Banffshire went, and they still hang on to Banffshire. (Huntly community council member)

Speyside is thus not a homogenous region in terms of physical environment, socio-economic orientation or sense of place. Whisky does form a tangible and intangible part of the landscape of a majority of the area but its specific institutionalisation has different forms and intensities depending on the particular location. Although it is a product that is present throughout the area and it extensively shapes the tourism destination image (see below), whisky cannot automatically be seen as a binding factor for Speyside communities.

\section{Power relations in whisky tourism commodification and institutionalisation}

Scottish destinations are marketed by VisitScotland with different purposes for different target audiences, focussing on visitor segments rather than individual products. The same destination is thus presented with a predominantly nature-based orientation for the domestic market versus a cultural focus for foreign markets:

In the UK market we tend to push the scenery and the peace and quiet and the activities a bit more, whereas overseas you promote the fact that we have a slightly different culture, of which whisky is a part. (Tourism manager, Highland Council)

Natural and cultural aspects of Scotland's landscape are thus mixed and presented differently to specific audiences depending on their socially constructed destination images (Buckley, Ollenburg, \& Zhong, 2008). While this overarching marketing of Scotland also influences Speyside, a themed focus on whisky does have a central place in more regional and local focuses in Moray itself. For instance Moray Tourism Development (MTD), the destination management organisation of Moray at the time of the research, branded the region as Moray Speyside - Spirit of Scotland, recognising the potential leverage of referring explicitly to whisky for tourism development in this area:

We weren't gonna call it Moray because nobody knows what Moray is, where Moray is. But people recognise Speyside, internationally renowned Speyside malts. (...) So eventually we came up with, that we would brand ourselves as Moray Speyside. (...) Now our approach to 
Post-print version from the article by Stoffelen \& Vanneste published in Scandinavian Journal of Hospitality and Tourism, 2015.

http://www.tandfonline.com/doi/full/10.1080/15022250.2015.1062416\#abstract

the brand is that whisky is the hook (...) but our way forward in developing tourism is that it isn't going to be necessarily our only priority. (Director, Moray Tourism Development)

Furthermore, the regional Moray Council reinforces this whisky-related symbolic shaping of the region by branding Moray "Malt Whisky Country" on roadside signs. Because of this, whisky distilleries have a central position in the destination.

In contrast, most of the distilleries themselves are not intrinsically interested in tourism because of relatively low potential returns on investment. Tourism is generally seen by them as a marketing means rather than a strategy to create direct profits. Nevertheless, the quality of most distillery visitor centres is high because the visitor attraction is envisioned to reflect the symbolic image of the product and its producer; almost one in four attractions in Scotland with the maximum of five stars on the quality assurance scheme of VisitScotland are whiskythemed (The Stevens View Partnership, 2007). The tourism coordinator of the Highland Council described this situation as follows:

It's very much linking the brand image of their product with the tourism side. You can't have a one star visitor centre if you're saying you've got the best whisky in the world. (Tourism manager, Highland Council)

In their marketing most distilleries emphasise their Scottish roots but with different intensities of reflection on the 'Scottishness' theme. Some distilleries use stereotypical Highland imageries such as tartan and bagpipe music in their visitor centres while others see this as artificial or inauthentic. Especially the use of kilts by tour guides is contentious:

It's traditional looking. We had them made especially for the employees just to make them... to make it look Scottish as well, because we do have a large amount of international visitors. (Representative distillery A; part of a large multinational company)

I don't wear a kilt (...) and one of the Dutch guys kept saying to me 'you should wear a kilt' and I said 'well you don't wear clogs'. (Representative distillery B; part of a relatively small company)

The commodified 'place-myth' (Urry, 1995) of Speyside is thus strongly shaped by the relatively high recognisability of the whisky-connoted Speyside name, despite VistScotland's overarching segmented (supra-)destination marketing. Because of the importance of whisky in 
Post-print version from the article by Stoffelen \& Vanneste published in Scandinavian Journal of Hospitality and Tourism, 2015.

http://www.tandfonline.com/doi/full/10.1080/15022250.2015.1062416\#abstract

this overall package, even when simply used as a lever to enhance other tourism offerings in the area, whisky companies are empowered to influence the symbolic shape of Speyside with their branding. These power balances facilitate a selectivity in destination commodification and institutionalisation that supports mostly extra-local perspectives (Knudsen et al., 2008; Urry, 1995). Consequently, the strategically presented identity of the region of Speyside contrasts with the institutionalisation of whisky in Speyside's cultural landscape and the rather heterogenous socio-spatial consciousness of its communities (Paasi, 1996, 2003, 2011).

\section{Reinforcing structures through multi-scalar destination institutionalisation}

As stated earlier, governance and institutionalisation structures are enforcing mechanisms in the web of relations between (commodified) territorial resources, stakeholders and development goals (Marsden, 2010). Paasi $(2003,2011)$ adds that these processes take place across a range of scales. The previous paragraph already described that the symbolic shaping of the destination has an important regional component through use of the Speyside name and reflection on the Scottishness theme in marketing of the identity of the region, which does not automatically match the socio-spatial consciousness of Speyside inhabitants on local scales. The territorial and institutional shaping of Speyside follow similar structures.

The aforementioned Moray Tourism Development (MTD) organisation aimed to provide a forum to bring public, private and community stakeholders together. Its DMO responsibilities of operationalising, managing and marketing the destination covered the whole Moray council area. At the time of the research MTD's power and return on investment for both small entrepreneurs and multinational companies were perceived by some to be small while its dependency on public sector money was high. This provided barriers in financial viability and legitimacy to operate as an overarching tourism platform. For instance, as one local entrepreneur replied when asked about MTD's operations:

They [MTD] have a huge part to play, but they're a very embryonic organisation (...) If you're wanting to bring people on board, tourism operators on board, you've got to provide them with something that is demonstrably value for money (...) You know, they don't do that at the moment. (Tourist accommodation entrepreneur in Speyside)

As a result of this situation, MTD ceased to exist in 2013. New efforts of establishing collaborative arrangements between public stakeholders and private entrepreneurs have 
Post-print version from the article by Stoffelen \& Vanneste published in Scandinavian Journal of Hospitality and Tourism, 2015.

http://www.tandfonline.com/doi/full/10.1080/15022250.2015.1062416\#abstract

developed in 2014 as part of the Moray Chamber of Commerce (MCC) under the name Moray Speyside, referring to the MTD brand. This institution with integrative aims is cofunded by Moray Council and the governmental economic development agency Highlands and Islands Enterprise Moray (HIE).

A second force that interlinks the territorial, institutional and symbolic shaping process of the destination on the regional scale is the Malt Whisky Trail (MWT). This well-known car-based tourism route that runs past several whisky-related places throughout Speyside (Martin \& McBoyle, 2006) is developed and managed by a private sector network consisting of 8 distilleries and a cooperage. Most of these stakeholders are protective of the Speyside brand seen as a marketing term supporting the product and image of the companies and region. The cultural Speyside boundaries are perceived to be impenetrable even though spatial extension of the trail may result in opportunities to spread gains of tourism over a larger area:

We'd have to keep it tight geographically, otherwise the whole idea of the thing is just worked up too much. (...) You have to stay in your category. (Representative distillery C; part of the MWT partnership)

We can't get into the Speyside whisky trail, obviously, we're outside Speyside by one mile (...) At the moment the Speyside trail [MWT] is a closed shop. They are very protective over their whisky trail and their partners. (Representative distillery D; not part of the MWT partnership)

Moreover, the MWT is not only a 'closed shop' for stakeholders outside Speyside but also for other actors such as smaller distilleries, community groups and the public sector that do not add enough brand value. This way, the integrative capacities of the MWT partnership remain limited.

A more inclusive regional institution exists in the form of the Spirit of Speyside Whisky Festival. The organisational structure of this biannual festival, with its main event in spring, has a lower entry barrier for community groups and local entrepreneurs. Moreover, the festival's activities sometimes surpass the Speyside boundaries (Figure 3). The organisation provides a, for Speyside rare, well-established regional forum through which tourism-related impacts can be spread out both socially and spatially and higher levels of integration can be reached. This shows that not the product as such but the assembly of the product, producers and related stakeholders into an integrative entity supports a socio-spatial spread of tourism- 
Post-print version from the article by Stoffelen \& Vanneste published in Scandinavian Journal of Hospitality and Tourism, 2015.

http://www.tandfonline.com/doi/full/10.1080/15022250.2015.1062416\#abstract

related benefits. In the MWT, exclusive commercial strategies and unequal power relations overrule such inclusive cooperation and co-creation.

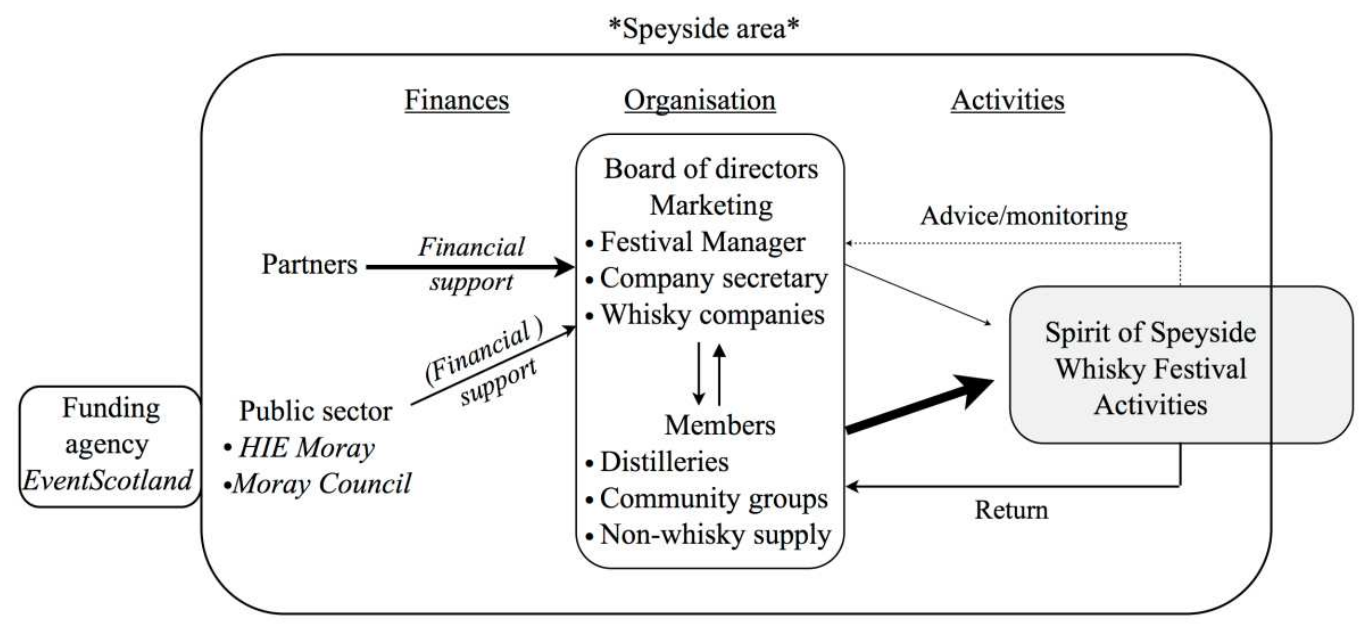

Figure 3. The organisational structure of the Spirit of Speyside Whisky Festival.

While most regional focuses of distillery enterprises are related to economic aspects of tourism development, their company identities are either global or global-local, depending on the presence or absence of local roots to complement the global business. The following quotes highlight this contrast:

We support our brands all over the world, we develop distribution all over the world, and basically a place like Speyside is of no tactical interest to us, compared to what we're doing all over the world. (Representative distillery C; part of a large multinational company)

It's a global business with its heart in the Highlands. Ultimately. (...) We're a global player. It's just that if you follow all those lines back, they will ultimately lead you to the door that you walked through this morning. (Representative distillery E; part of a large multinational, family-owned company)

Local roots of whisky distilleries sometimes reflect in economic support at a village level, thereby creating a local (identity-based) component to the destination institutionalisation. Local community and entrepreneurial groups such as Dufftown2000 are key institutions to establish direct linkages with these distilleries and their tourism practices. However, because of differences between companies, with some being more proactive than others, and between 
Post-print version from the article by Stoffelen \& Vanneste published in Scandinavian Journal of Hospitality and Tourism, 2015.

http://www.tandfonline.com/doi/full/10.1080/15022250.2015.1062416\#abstract

interpretations of stakeholders with different scalar viewpoints, the valuation of the engagement of distilleries with communities differs from place to place and depends on the scale and person of reference:

[Regarding a local distillery with visitor centre:] They've always been very supportive of any development in Dufftown itself. (...) If they ever shut their doors, I think the tourist trade would just die. And so would the village. But it keeps the shops and the restaurants going and keeps us thriving. (Local entrepreneur \& Dufftown2000 member)

I think they [the distilleries in general] do engage fairly well but I think they probably could do more but it's difficult for them to do that because they have a brand to protect. (...) But, this is not an individual view, this is I think a general public sector view, there's a feeling that they possibly could do more. (Manager, HIE Moray)

The tourism commodification and institutionalisation process of Speyside is thus framed by several scalar structures. The institutional shape is managed on a regional level with central positions for globally connected distilleries, a private sector network (MWT) and a currently unsettled community and entrepreneurial partnership group (previously MTD, now MCC). This regional institutionalisation is formed mostly in economic terms. It contrasts with identity differences among individual communities and rather locally focused social commitments of some distilleries. While this sometimes does provide a highly significant complex between distilleries and community stakeholders, mostly through local community groups, gaps exist between these local interrelations, the regional destination organisation and the global positioning of most whisky producers. Together with the current absence of a successful, integrative regional platform the challenge remains significant for small tourismrelated stakeholders to structurally bundle their forces in the management of whisky tourism on a Speyside level, which only reinforces present power relations.

\section{Discussion: development implications of regional (dis)integration of whisky tourism}

In order to better understand the potential of tourism as a regional development strategy, analysis should focus on the level of integration of tourism in larger region-building processes. To reach these integration levels, all stakeholders should be empowered in the development and management of tourism on a destination level (Saarinen, 2003; Saxena et 
Post-print version from the article by Stoffelen \& Vanneste published in Scandinavian Journal of Hospitality and Tourism, 2015.

http://www.tandfonline.com/doi/full/10.1080/15022250.2015.1062416\#abstract

al., 2007). However, uneven power relations and the scalar configuration of the destination institutionalisation put the embeddedness (the linkages with local socio-cultural relations and knowledge) and the endogeneity (the touristic use of emplaced resources and the local retaining of related benefits) of whisky tourism in Speyside under pressure (Oliver \& Jenkins, 2003; Saxena et al., 2007; Saxena \& Ilbery, 2008). Despite the agency of tourism in the region-building process of Speyside due to its active role in the region's territorial, symbolic and institutional shaping, the selectivity in institutionalisation provides an unstable foundation for integration of all stakeholders in destination-level processes. The position of whisky tourism in Speyside thus currently institutionalises the gap between the relatively homogenous presentation of the identity of the region, using whisky for its branding, and the locally diverse position of whisky in the Speyside cultural landscape. The presence of this institutionalised gap raises questions about the authenticity and long-term viability of stereotyped focuses on Scottishness (see Spracklen, 2011), even though this brand has also been recognised as a key factor for Scotland's success as an international tourism destination (Butler, 1998). Moreover, the gap reflects different interests of global and local-regional stakeholders in the area. While both strive for increasing competitiveness of the Speyside destination, they do so with different goals and institutional power positions. This multi-scalar stakeholder diversity reinforces the difficulty to align their capacities, knowledge and aims in an inclusive management process.

Integrative development concepts provide frameworks to move beyond this situation. The concept of the rural web highlights that the mode of interaction between physical-territorial and human settings of destinations is key in the relational structure between actors, activities and resources, and consequently can be seen as a constitutive force in the region-building process (Marsden, 2010; Ventura et al., 2008). With reference to Speyside, the distilleries are dependent on their spatial rooting for both whisky production and tourism development. The Speyside landscape provides outstanding natural resources to support whisky distillation, while the brand image of distillery visitor centres is critically dependent not only on the symbolic product characteristics but also on the local community and landscape context (McBoyle \& McBoyle, 2008; Spracklen, 2011). Whisky distilling and whisky tourism thus result from the combination of global market operations and a fixed spatial location of distilleries. 
Post-print version from the article by Stoffelen \& Vanneste published in Scandinavian Journal of Hospitality and Tourism, 2015.

http://www.tandfonline.com/doi/full/10.1080/15022250.2015.1062416\#abstract

One view on this situation is that it is impossible to relocate a distillery to an economically more rational location. This virtually forced multinational distillery enterprises to invest in an area that some claim is of no specific strategic interest to them. A contrasting vision is that they are 'indebted' to the region since they would not be in business without the use of its territorial resources. This gives possibilities to raise awareness, among local communities that a basis is available to engage on a more equal footing with these companies, and among distilleries that they have a responsibility due to their use of territorial resources with a common ownership base (Ventura et al., 2008). To increase embeddedness and endogeneity, the mobilisation of resources for tourism thus needs to be reconfigured, also in its institutional settings, by building explicitly on their distinct local and regional characteristics and embeddedness in the physical and cultural landscape (Marsden, 2010; Oliver \& Jenkins, 2003). This recognition is present in some localities due to community support by distilleries. However, this local engagement also creates a spatial unevenness in development as not every distillery company is as proactive in making this effort. Moreover, in some places a local forum comparable to Dufftown2000 is not present to facilitate this relational process by providing a strong local voice to absorb and spread the potential arrangements among the distilleries.

Further, the socio-economic spread of tourism-related impacts cannot be taken for granted. While local support may indeed be of key importance in some places, the step up from the local to the regional level, which is seen as the natural unit of management and marketing of the destination, can only be made by already empowered stakeholders. Current entrepreneurial and community efforts are largely limited to providing amenities, supportive services and relatively small-scale tourism products and activities without structurally influencing the regional institutionalisation of the destination itself. This way, they indirectly reinforce currently unequal power relations in the destination.

A multistage empowerment process using local community groups as delivery mechanisms for regional networking could provide a basis for more integrated and emplaced linking up of assets within a coherent framework. The development of the Moray Speyside regional platform is a significant first step to increase the inclusivity of the local into the regional institutional shape of Speyside through multi-scalar activities, countering the presently undermined levels of integration in the 'regional establishment' sphere of the region-building process (Paasi, 1996, 2009, 2011). Moreover, (re)building the social capital could provide 
Post-print version from the article by Stoffelen \& Vanneste published in Scandinavian Journal of Hospitality and Tourism, 2015.

http://www.tandfonline.com/doi/full/10.1080/15022250.2015.1062416\#abstract

support for a more participatory style of institutionalisation (Marsden, 2010). A larger continuity of these institutional structures and a less restricting vision towards the destination delineation are key requirements in such regional development contexts (see e.g. Saarinen, 2003). The volatility in management organisations and the commercially exclusive Speyside boundary politics of empowered stakeholders currently undermine the stability and integration of destination management processes. The long-term inclusion of more voices and destinies in these processes, for instance those of communities and local entrepreneurs, can fuel a wider spatial distribution of images used. Increasing the spatial and social spread of tourism impacts in this way may even influence areas such as Buckie that are less directly connected to whisky (tourism), and extend beyond the direct Speyside boundaries.

\section{Conclusion}

This paper aimed to understand the mechanisms behind the presence or absence of the implementation gap to employ tourism as a regional development strategy in rural areas. The paper has added to the debate on tourism and regional development in two ways. First, by exploring the role of tourism in region-building processes it has conceptually expanded the notion that tourism should be integrated in regional contexts in order to be able to act on development aims. Second, it has provided empirical insights on these mechanisms through a case study on whisky tourism in Speyside, Scotland.

In Speyside, whisky distilleries are of central importance to the regional economy in general, and to the tourism destination in particular, through the provision of a high-profile regional brand, visitor centres of outstanding quality and integration with external markets. Whisky tourism plays an active role in interlinking the territorial, symbolic and institutional shaping of the region and is thereby an active agent in region-building processes in Speyside (Paasi, 1996, 2011). However, our analysis of this region-building process has showed that regional inclusivity is not guaranteed and that this is one of the key factors behind the noted 'missed opportunity' to gain more from whisky tourism (BBC Scotland, 2013). The configuration of territorial resources in destination commodification and institutionalisation provides an unstable basis for regional integration of whisky tourism, creating a situation in which a large potential is present but the regional benefits are still middling. The required balance between endogeneity-exogeneity and embeddedness-disembeddedness to use tourism for regional development is thus not present as of yet in Speyside. Global-local contrasts between goals 
Post-print version from the article by Stoffelen \& Vanneste published in Scandinavian Journal of Hospitality and Tourism, 2015.

http://www.tandfonline.com/doi/full/10.1080/15022250.2015.1062416\#abstract

and power positions of stakeholders currently limit the destination-wide dispersal of tourismrelated benefits. Additionally, analysis of the interaction between human and physicalterritorial settings in Speyside has indicated that the lack of reflection at a destination level of the spatial rootedness of tourism in the web of relations between actors, activities and resources further undermines this balance. Hence, this research renders support for the value of the reflection on place identity narratives in destination management practices. This is particularly relevant in similar rural contexts of northern Europe that are characterised by well-developed nature-based and cultural assets as well as local identity structures.

Moreover, multi-scalar aspects in the regional institutionalisation of tourism showed to be pivotal in the establishment and confirmation of power relations in commodification of territorial resources and in use of social capital. Multi-scalar structures comparable to the currently developing tourism organisation in the Moray Chamber of Commerce provide potential carriers that facilitate regional integration of local interests and hence mechanisms to bridge this scalar gap. Destination-wide provision of institutional support for local networking agencies such as local community and entrepreneurial organisations would also provide a highly useful strategy to increase the socially and spatially integrative position of tourism in region-building processes of rural destinations.

A shortcoming of this paper is the omission of tourists in the research set-up. Tourists are increasingly seen as important stakeholders in the co-creation of destination images and hence as potential mediators between tourist identities and destination identities (van der Zee \& Go, 2013). This could especially be the case for whisky tourism due to the symbolic lifestyle values of the product (Spracklen, 2011). Future research may shed light on the role of tourists as facilitators of a more inclusive destination structure, thereby potentially empowering community and local entrepreneurial stakeholders on a destination level.

\section{References}

Adiyia, B., Stoffelen, A., Jennes, B., Vanneste, D., \& Ahebwa, W. M. (2015). Analysing governance in tourism value chains to reshape the tourist bubble in developing countries: The case of cultural tourism in Uganda. Journal of Ecotourism, 1-17. doi:10.1080/14724049.2015.1027211

BBC Scotland. (2013). Moray whisky trail "a missed opportunity.” Retrieved February 13, 2014, from http://www.bbc.co.uk/news/uk-scotland-20998721 
Post-print version from the article by Stoffelen \& Vanneste published in Scandinavian Journal of Hospitality and Tourism, 2015.

http://www.tandfonline.com/doi/full/10.1080/15022250.2015.1062416\#abstract

Bosak, K., Boley, B., \& Zaret, K. (2010). Deconstructing the "Crown of the Continent": Power, politics and the process of creating National Geographic's geotourism mapguides. Tourism Geographies, 12(3), 460-480. doi:10.1080/14616688.2010.494686

Bramwell, B. (2010). Participative planning and governance for sustainable tourism. Tourism Recreation Research, 35(3), 239-249. doi:10.1080/02508281.2010.11081640

Bramwell, B. (2011). Governance, the state and sustainable tourism: A political economy approach. Journal of Sustainable Tourism, 19(4-5), 459-477. doi:10.1080/09669582.2011.576765

Briedenhann, J., \& Wickens, E. (2004). Tourism routes as a tool for the economic development of rural areas - Vibrant hope or impossible dream? Tourism Management, 25(1), 71-79. doi:10.1016/S0261-5177(03)00063-3

Buckley, R., Ollenburg, C., \& Zhong, L. (2008). Cultural landscape in Mongolian tourism. Annals of Tourism Research, 35(1), 47-61. doi:10.1016/j.annals.2007.06.007

Burns, P. (1999). Paradoxes in planning: Tourism elitism or brutalism? Annals of Tourism Research, 26(2), 329-348. doi:10.1016/S0160-7383(98)00099-1

Butler, R. (1998). Tartan mythology: The traditional tourist image of Scotland. In G. Ringer (Ed.), Destinations: Cultural landscapes for tourism (pp. 121-139). London: Routledge.

Cantrill, J. G., \& Senecah, S. L. (2001). Using the "sense of self-in-place" construct in the context of environmental policy-making and landscape planning. Environmental Science \& Policy, 4(4-5), 185-203. doi:10.1016/S1462-9011(01)00023-5

Cunningham, P. (2009). Exploring the cultural landscape of the Obeikei in Ogasawara, Japan. Journal of Tourism and Cultural Change, 7(3), 221-234. doi:10.1080/14766820903267371

Douglas, J. A. (2014). What's political ecology got to do with tourism? Tourism Geographies, 16(1), 8-13. doi:10.1080/14616688.2013.864324

Fraser, D. (2013). Whisky tax “could benefit Scots." BBC Scotland. Retrieved February 24, 2015, from http://www.bbc.com/news/uk-scotland-20931496

George, E. W., Mair, H., \& Reid, D. G. (2009). Rural tourism development: Localism and cultural change. Bristol: Channel View Publications.

Greider, T., \& Garkovich, L. (1994). Landscapes: The social construction of nature and the environment. Rural Sociology, 59(1), 1-24. doi:10.1111/j.1549-0831.1994.tb00519.x

Hall, C. M. (2005). Tourism: Rethinking the social science of mobility. Harlow: Pearson Education Limited. 
Post-print version from the article by Stoffelen \& Vanneste published in Scandinavian Journal of Hospitality and Tourism, 2015.

http://www.tandfonline.com/doi/full/10.1080/15022250.2015.1062416\#abstract

Hughes, G. (1998). Tourism and the semiological realization of space. In G. Ringer (Ed.), Destinations: Cultural landscapes for tourism (pp. 17-32). London: Routledge.

Jansen-Verbeke, M. (2013). The mutation of cultural landscapes: The "unplanned" tourism map of Europe. In C. Costa, E. Panyik, \& D. Buhalis (Eds.), Trends in European tourism planning and organisation (pp. 15-32). Bristol: Channel View Publications.

Kauppila, P., Saarinen, J., \& Leinonen, R. (2009). Sustainable tourism planning and regional development in peripheries: A Nordic view. Scandinavian Journal of Hospitality and Tourism, 9(4), 424-435. doi:10.1080/15022250903175274

Kneafsey, M. (2001). Rural cultural economy: Tourism and social relations. Annals of Tourism Research, 28(3), 762-783. doi:10.1016/S0160-7383(00)00077-3

Knudsen, D. C., Metro-Roland, M. M., Soper, A. K., \& Greer, C. E. (Eds.). (2008). Landscape, tourism, and meaning. Aldershot: Ashgate Publishing Limited.

Marsden, T. (2010). Mobilizing the regional eco-economy: Evolving webs of agri-food and rural development in the UK. Cambridge Journal of Regions, Economy and Society, 3(2), 225-244. doi:10.1093/cjres/rsq010

Martin, A., \& McBoyle, G. (2006). Scotland's Malt Whisky Trail: Management issues in a public-private tourism marketing partnership. International Journal of Wine Marketing, 18(2), 98-111. doi:10.1108/09547540610681086

McBoyle, G., \& McBoyle, E. (2008). Distillery marketing and the visitor experience: A case study of Scottish malt whisky distilleries. International Journal of Tourism Research, 10(1), 71-80. doi:10.1002/jtr

Milne, S., \& Ateljevic, I. (2001). Tourism, economic development and the global-local nexus: Theory embracing complexity. Tourism Geographies, 3(4), 369-393. doi:10.1080/146166800110070478

Oliver, T., \& Jenkins, T. (2003). Sustaining rural landscapes: The role of integrated tourism. Landscape Research, 28(3), 293-307. doi:10.1080/01426390306516

Ordnance Survey. (2012). OS OpenData. Retrieved October 29, 2012, from https://www.ordnancesurvey.co.uk/oswebsite/products/os-opendata.html

Paasi, A. (1996). Territories, boundaries and consciousness. Chichester: John Wiley \& Sons Ltd.

Paasi, A. (2003). Region and place: Regional identity in question. Progress in Human Geography, 27(2003), 475-485. doi:10.1191/0309132503ph439pr

Paasi, A. (2009). The resurgence of the "Region" and "Regional Identity": Theoretical perspectives and empirical observations on regional dynamics in Europe. Review of International Studies, 35(S1), 121-146. doi:10.1017/S0260210509008456 
Post-print version from the article by Stoffelen \& Vanneste published in Scandinavian Journal of Hospitality and Tourism, 2015.

http://www.tandfonline.com/doi/full/10.1080/15022250.2015.1062416\#abstract

Paasi, A. (2011). The region, identity, and power. Procedia - Social and Behavioral Sciences, 14, 9-16. doi:10.1016/j.sbspro.2011.03.011

Parra, C. (2010). Sustainability and multi-level governance of territories classified as protected areas in France: The Morvan regional park case. Journal of Environmental Planning and Management, 53(4), 491-509. doi:10.1080/09640561003737341

Ringer, G. (Ed.). (1998). Destinations: Cultural landscapes for tourism. London: Routledge.

Saarinen, J. (2003). The regional economics of tourism in northern Finland: The socioeconomic implications of recent tourism development and future possibilities for regional development. Scandinavian Journal of Hospitality and Tourism, 3(2), 91-113. doi:10.1080/15022250310001927

Saarinen, J. (2004). Tourism and touristic representations of nature. In A. A. Lew, C. M. Hall, \& A. M. Williams (Eds.), A companion to tourism (pp. 438-449). Malden, Oxford, Carlton: Blackwell Publishing. doi:10.1002/9780470752272.ch35

Saarinen, J. (2007). Tourism in peripheries: The role of tourism in regional development in northern Finland. In D. K. Müller \& B. Jansson (Eds.), Tourism in peripheries: Perspectives from the far north and south (pp. 41-52). Wallingford: CAB International. doi:10.1079/9781845931773.0000

Sampson, K. A., \& Goodrich, C. G. (2009). Making place: Identity construction and community formation through "sense of place" in Westland, New Zealand. Society \& Natural Resources, 22(10), 901-915. doi:10.1080/08941920802178172

Saxena, G., Clark, G., Oliver, T., \& Ilbery, B. (2007). Conceptualizing integrated rural tourism. Tourism Geographies, 9(4), 347-370. doi:10.1080/14616680701647527

Saxena, G., \& Ilbery, B. (2008). Integrated rural tourism: A border case study. Annals of Tourism Research, 35(1), 233-254. doi:10.1016/j.annals.2007.07.010

Scotch Whisky Association. (2009). The Scotch Whisky regulations 2009. Retrieved March 4, 2015, from http://www.scotchwhisky.org.uk/media/12744/scotchwhiskyregguidance2009.pdf

Scotch Whisky Association. (2010). The world of Scotch Whisky. Retrieved October 30, 2012, from http://www.scotchwhisky.org.uk/media/17027/theworldofscotch_whisky2010.pdf

Scotch Whisky Association. (2011). Scotch Whisky and tourism. Edinburgh: 4-Consulting. Retrieved March 4, 2015, from http://www.scotchwhisky.org.uk/media/16876/scotchwhiskyandtourismreport.pdf

Scotch Whisky Association. (2015). The economic impact of Scotch Whisky production in the UK. Edinburgh: 4-Consulting. Retrieved March 4, 2015, from http://www.scotchwhisky.org.uk/media/70534/economic_impact_20pp_web_v2.pdf 
Post-print version from the article by Stoffelen \& Vanneste published in Scandinavian Journal of Hospitality and Tourism, 2015.

http://www.tandfonline.com/doi/full/10.1080/15022250.2015.1062416\#abstract

Scottish Natural Heritage. (2002). Natural Heritage Futures - An Overview. Retrieved February 13, 2014, from http://www.snh.gov.uk/docs/A337645.pdf

Sofield, T. H. B. (2003). Empowerment for sustainable tourism development. Oxford: Pergamon.

Spracklen, K. (2011). Dreaming of drams: Authenticity in Scottish whisky tourism as an expression of unresolved Habermasian rationalities. Leisure Studies, 30(1), 99-116. doi:10.1080/02614367.2010.502240

Stoffelen, A., \& Vanneste, D. (2015). An integrative geotourism approach: Bridging conflicts in tourism landscape research. Tourism Geographies, (forthcoming). doi:10.1080/14616688.2015.1053973

The Stevens View Partnership. (2007). Moray tourism audit. prepared for Highlands and Islands Enterprise Moray, September 2007.

Timothy, D. J. (1998). Cooperative tourism planning in a developing destination. Journal of Sustainable Tourism, 6(1), 52-68. doi:10.1080/09669589808667301

Timothy, D. J., \& Boyd, S. W. (2014). Tourism and trails: Cultural, ecological and management issues. Bristol: Channel View Publications.

Urry, J. (1995). Consuming places. London: Routledge.

Uusitalo, M. (2010). Differences in tourists' and local residents' perceptions of tourism landscapes: A case study from Ylläs, Finnish Lapland. Scandinavian Journal of Hospitality and Tourism, 10(3), 310-333. doi:10.1080/15022250.2010.489786

Van der Zee, E., \& Go, F. M. (2013). Analysing beyond the environmental bubble dichotomy: how the 2010 World Cup case helped to bridge the host-guest gap. Journal of Sport \& Tourism, 18(3), 161-183. doi:10.1080/14775085.2014.888674

Vanneste, D., \& Ryckaert, L. (2012). Governance in the tourism practice. Entrepreneurial attitudes. In E. Fayos-Solas, J. Albino Matos de Silva, \& J. Jafari (Eds.), Knowledge management in tourism: Policy and governance applications (pp. 303-323). Bingley (UK): Emerald.

Ventura, F., Brunori, G., Milone, P., \& Berti, G. (2008). The rural web: A synthesis. In J. D. van der Ploeg \& T. Marsden (Eds.), Unfolding webs: The dynamics of regional rural development (pp. 149-175). Assen: Van Gorcum.

Waterton, E. (2005). Whose sense of place? Reconciling archaeological perspectives with community values: Cultural landscapes in England. International Journal of Heritage Studies, 11(4), 309-325. doi:10.1080/13527250500235591 
Post-print version from the article by Stoffelen \& Vanneste published in Scandinavian Journal of Hospitality and Tourism, 2015.

http://www.tandfonline.com/doi/full/10.1080/15022250.2015.1062416\#abstract

Wray, K., Espiner, S., \& Perkins, H. C. (2010). Cultural clash: Interpreting established use and new tourism activities in protected natural areas. Scandinavian Journal of Hospitality and Tourism, 10(3), 272-290. doi:10.1080/15022250.2010.496570

\section{Acknowledgements}

This work was supported by the Research Foundation - Flanders (FWO). The authors wish to thank the stakeholders in Speyside who addressed them for this research. The authors are indebted to Bright Adiyia, Katarzyna Janusz, Egbert van der Zee, the editors and anonymous reviewers for their valuable comments. 